Article

\title{
Bisphenol A Exposure and Sperm ACHE Hydroxymethylation in Men
}

\author{
Xiuxia Song ${ }^{1,+}$, Maohua Miao ${ }^{1,+}{ }^{\dagger}$, Xiaoyu Zhou ${ }^{2}$, Dekun Li $^{3}$, Youping Tian ${ }^{1,4}$, Hong Liang ${ }^{1}$, \\ Runsheng $\mathrm{Li}^{1, *}$ and Wei Yuan ${ }^{1, *}$ \\ 1 Key Laboratory of Reproduction Regulation of NPFPC, SIPPR, IRD, Fudan University, Shanghai 200237, \\ China; xxsong1212@163.com (X.S.); miaomaohua@sippr.org.cn (M.M.); 16211150003@fudan.edu.cn (Y.T.); \\ lianghong@sippr.org.cn (H.L.) \\ 2 Shanghai Tongshu Biotechnology Co., Ltd., Shanghai 200237, China; zouxy2001@163.com \\ 3 Division of Research, Kaiser Foundation Research Institute, Kaiser Permanente Northern California, \\ Oakland CA 94612, USA; dk1@dor.kaiser.org \\ 4 School of Public Health, Fudan University, Shanghai 200237, China \\ * Correspondence: runshengli2007@163.com (R.L.); yuanwei11@yahoo.com (W.Y.) \\ $\dagger$ The authors contributed equally to the publication.
}

Received: 29 November 2018; Accepted: 1 January 2019; Published: 8 January 2019

check for updates

\begin{abstract}
Exposure to bisphenol A (BPA) has been shown to impact human sperm quality. The epigenetic mechanisms underlying the effect remain unknown. The acetylcholinesterase (ACHE) gene is a sperm-expressed gene encoding the acetylcholine hydrolyzing enzyme acetylcholinesterase and participates in the apoptosis of cells, including sperm. This study aimed to examine whether BPA exposure is associated with the hydroxymethylation level of the sperm $A C H E$ gene. A total of 157 male factory workers were studied, among whom 74 had BPA exposure in the workplace (BPA exposure group) and 83 had no BPA exposure in the workplace (control group). Urine samples were collected for BPA measurement and semen samples were collected to assay for $A C H E$ hydroxymethylation. Sperm $A C H E$ hydroxymethylation level was higher in the BPA exposure group ( $p=0.041)$ compared to the control group. When subjects were categorized according to tertiles of detected BPA level, higher ACHE hydroxymethylation levels were observed for the lowest, middle, and top tertiles compared to those with BPA below the limit of detection (LOD). In a linear regression analysis adjusted for confounders, a positive linear association between urine BPA concentration and 5-hydroxymethylcytosine $(5 \mathrm{hmC})$ rate of the sperm $A C H E$ gene was observed, although the association did not reach statistical significance in all categories after being stratified by the BPA tertile. In conclusion, $5 \mathrm{hmC}$ of the sperm $A C H E$ gene was positively associated with BPA exposure, which may provide supportive evidence for BPA's effects on male fertility or other health endpoints.
\end{abstract}

Keywords: bisphenol A; ACHE; DNA hydroxymethylation; sperm

\section{Introduction}

Bisphenol A (BPA) is a synthetic industrial chemical that has been widely used in the manufacturing of polycarbonate plastic and epoxy resins, such as water and baby bottles, reusable food and drink containers and some dental sealants. BPA can enter the body through diet, the dermis, and the respiratory tract [1-3]. Exposure to BPA has gained wide attention over the past decades due to its ubiquitous exposure and potential endocrine disrupting effects, including weak estrogenic and strong anti-androgenic and anti-thyroid activities [4-7]. An increasing body of evidence has shown that exposure to BPA is associated with higher risks of adverse health effects in humans, including cardiovascular disease, insulin resistant diabetes, obesity, and cancers [8-11]. Particularly, BPA 
exposure is associated with impaired male reproductive functions, including reduced semen quality, altered reproductive hormones, and decreased sexual function [12-16]. However, the mechanisms underlying these effects remain to be elucidated.

Epigenetic mechanisms have been demonstrated to play an important role in BPA's biological effects, including the effects on spermatogenesis [17,18]. For instance, long interspersed element-1 (LINE-1), the most abundant and the only active autonomous non-long terminal repeats (non-LTR) retrotransposon in the human genome, showed an alteration in methylation following BPA exposure [19]. However, little is known about how BPA modulates DNA demethylation. An essential intermediate of active DNA demethylation processes, 5-hydroxymethylcytosine ( $5 \mathrm{hmC})$, which is oxidized from 5-methylcytosine $(5 \mathrm{mC})$ by the ten-eleven translocation (TET) family of proteins, has been reported to modulate the demethylation associated with BPA $[17,20,21]$. A recent animal study reported that exposure to BPA inhibits global DNA hydroxymethylation in the adult testis and decreases testicular TETs [22]. More importantly, in our recent study based on pooled human sperm, the total level of $5 \mathrm{hmC}$ increased significantly in subjects with BPA exposure [23]. 5hmC may be another unique and dynamic marker of DNA demethylation regulation [24,25].

The acetylcholine hydrolyzing enzyme acetylcholinesterase (ACHE) is conventionally known for terminating cholinergic neurotransmission. However, non-cholinergic roles of ACHE are observed in animal and human sperm [26,27]. ACHE has been shown to be a potential marker and regulator of apoptosis in some cells [28-30]. Studies have also revealed the functions of ACHE during spermatogenesis, including interactions with the receptor of activated protein kinase C (RACK1) to promote apoptosis and with the glycolytic enzyme enolase- $\alpha$, increasing enolase activity, to reduce sperm differentiation and sperm counts [31,32]. Our recent study based on pooled samples found that the $5 \mathrm{hmC}$ levels of promoter regions in sperm-expressed genes (including ACHE gene) are significantly higher than in sperm-repressed genes and that the $A C H E$ gene is a sperm-expressed gene [23]. The objective of our study was to examine the association between BPA and $5 \mathrm{hmC}$ in the sperm $A C H E$ gene in individuals, which may help us understand the mechanism of BPA's effects on male fertility.

\section{Materials and Methods}

\subsection{Study Population}

Male participants came from a prospective cohort study that has been described in detail elsewhere [12,19,33]. In brief, 74 males were recruited from factories that manufacture BPA and epoxy resin in three regions (Ningbo, Wuxi, and Yueyang) of China from 2004 to 2008 (BPA exposure group) and 83 males from factories without occupational BPA exposure in the same region during the same period (control group). The study was approved by the ethics committee board of the Shanghai Institute of Planned Parenthood Research (IRB00008297), and all participants signed informed consent before participating in the study.

\subsection{Data and Biosamples Collection}

Information on socio-demographic characteristics (age and education), lifestyle factors (smoking and alcohol consumption), and history of disease (any acute or chronic disease of the liver, kidney, or other organs) were collected through in-person interviews by trained interviewers. Semen and urine samples were also collected at the same time using the methods previously described [12,19].

\subsection{BPA Measurement}

BPA can be measured in various biological samples. Although plasma, urinary, and seminal BPA are correlated with each other [34-36], urinary BPA is most widely used in epidemiological studies [37]. In the present study, we only measured urinary BPA concentration of the workers. We did not have measurements of BPA levels in semen. Two urine samples (pre-shift and post-shift) were collected from each male worker of the BPA-exposed group, and one urine sample was collected from those of the 
control group. For each urine specimen, modified high-performance liquid chromatography (HPLC) was utilized to measure the total urine BPA concentration (free plus conjugated species), as previously described [38]. Briefly, urine samples were treated with phosphorous acid buffer/ $\beta$-glucuronidase for hydrolyzation and were subsequently extracted twice using ether (HPLC grade, Dikma, Foothill Ranch, CA, USA). The supernatants were collected and evaporated with nitrogen gas. The residue was dissolved in $60 \%$ acetonitrile and analyzed using HPLC equipment. The limit of detection (LOD) was $0.31 \mu \mathrm{g} / \mathrm{L}$. Creatinine-corrected ( $\mu \mathrm{g} / \mathrm{g}$ creatinine) BPA concentration was used in the analyses to account for urine dilution. To better represent the actual BPA exposure levels for the BPA-exposed group, the mean BPA concentrations of the pre-shift and post-shift samples were used in the analysis.

\subsection{DNA Extraction and DNA Hydroxymethylation Analysis}

The sperm DNA was prepared as described previously [19]. Briefly, sperm specimens were treated by guanidine hydrochloride and sodium citrate to isolate sperm pellets, and then precipitated with ethanol. Then, sperm DNA was isolated by a standard phenol/chloroform purification method and qualified by electrophoresis on an agarose gel and visualized with ethidium bromide.

$5 \mathrm{hmC}$ was analyzed and quantitated using the EpiMark 5hmC and 5mC Analysis Kit (NEB, \#E3317S) according to the manufacturer's protocols. Briefly, DNA was first mixed with UDP-glucose, then split into two parts that were incubated with or without T4 beta-glucosyltransferase (T4- $\beta G T$ ), respectively, for $16 \mathrm{~h}$ at $37^{\circ} \mathrm{C}$. This glucosylation was followed by restriction endonuclease digestion. Both reaction mixtures were run in triplicate and were mock digested for at least $4 \mathrm{~h}$ with MspI or with HpaII. Samples were treated with proteinase $\mathrm{K}$ and incubated at $40{ }^{\circ} \mathrm{C}$ for $30 \mathrm{~min}$. Proteinase $\mathrm{K}$ was then inactivated by incubating at $95^{\circ} \mathrm{C}$ for $10 \mathrm{~min}$. The fraction of glycosylated DNA and, therefore, protected MspI sites, as well as the fraction of 5mCand 5hmCsensitive sites (determined using HpaII restriction) at $A C H E$ gene loci, were quantified by quantitative polymerase chain reaction (qPCR) using primers (F-ATGCAGTGACAGGCACAGAC, R-TGAGTGTCCCACGTCACCTTT). The rate of hydroxymethylation was calculated using the formulae in the kit according to the manufacturer's protocols.

\subsection{Statistical Analysis}

The distributions of creatinine-corrected BPA concentrations by subjects' characteristics were tabulated. The urine BPA concentrations were natural log $(\ln )$ transformed to achieve a normal distribution and then an independent $t$-test or one-way ANOVA analysis was performed to analyze differences in BPA levels. When the concentration of BPA was below the limit of detection, a value of LOD $/ \sqrt{ } 2$ was employed. To make the results more interpretable, we classified subjects with detected urine BPA levels into three categories. Therefore, all subjects were divided into four groups: BPA undetected (lower than the LOD level), lowest tertile, middle tertile, and top tertile. Means (SD) and 5th, 25th, 50th, 75th, and 95th percentiles of 5hmC rates of sperm ACHE gene were used to describe the distribution of $5 \mathrm{hmC}$ by occupational BPA exposure (yes or no) and the urine BPA levels. Rates of $5 \mathrm{hmC}$ were then natural $\log (\mathrm{ln})$ transformed to achieve a normal distribution for the linear regression analysis, which was used to examine the association between categorized BPA exposure and 5hmC. Age, smoking, alcohol consumption, and history of disease, which had been reported to be associated with $5 \mathrm{hmC}$ [39-41], were adjusted for as potential confounders.

We also conducted a linear regression analysis to examine the linear association between BPA exposure and $5 \mathrm{hmC}$ using continuous BPA level (log transformed). We repeated the analyses within each tertile of urine BPA to examine whether the association varied by exposure dosage. Subgroup analyses were also conducted in the non-occupational exposed group, results of which reflect the effect of environmental low dose BPA exposure and would corroborate the findings to some extent. All statistical analyses were performed using SPSS 19.0 software package (IBM SPSS, Armonk, NY, USA). 


\section{Results}

The detection rates of urinary BPA levels in the exposure group and control group were $100 \%$ and $36.14 \%$, respectively. The mean BPA concentrations in the pre-shift and post-shift samples were used in the exposure group. The difference and distribution of BPA levels between the pre-shift and post-shift exposure groups are presented in a supplemental table (Table S1). BPA levels by the characteristics of the study subjects are presented in Table 1. Compared to men with middle school or below, BPA levels in those with high school and with college and above were relatively lower (Table S2). The most important determinants for a high BPA level in this study population was occupational exposure. The geometric mean (GM) of BPA concentration in the occupational BPA exposure group was significantly higher than that of the control group $(199.13 \mu \mathrm{g} / \mathrm{g} \mathrm{Cr}$ vs. $0.77 \mu \mathrm{g} / \mathrm{g} \mathrm{Cr})$. The GM of BPA levels were $3.93 \mu \mathrm{g} / \mathrm{g} \mathrm{Cr}, 42.58 \mu \mathrm{g} / \mathrm{g} \mathrm{Cr}$, and $2937.79 \mu \mathrm{g} / \mathrm{g}$ Cr for the lowest, middle, and top tertiles, respectively. Urine BPA levels were not associated with age, history of chronic diseases, smoking, and alcohol consumption. 
Table 1. Distribution of urine bisphenol A (BPA) by characteristics of the study population ( $\mu \mathrm{g} / \mathrm{g} \mathrm{Cr})$.

\begin{tabular}{|c|c|c|c|c|c|c|c|c|}
\hline \multirow{2}{*}{ Characteristics } & \multicolumn{8}{|c|}{ BPA ( $\mu \mathrm{g} / \mathrm{g}$ Cr) } \\
\hline & N (157) & GM (GSD) & Median (Q1, Q3) & Minimum & Maximum & 5th & 95th & $p$ Value $^{\text {cd }}$ \\
\hline \multicolumn{9}{|l|}{ Age (years) } \\
\hline$<29$ & 55 & $10.91(32.94)$ & 7.90 (LOD, 61.00) & LOD & $109,600.22$ & LOD & $22,991.39$ & 0.81 \\
\hline 30-35 & 39 & $10.60(17.55)$ & $11.67(1.45,43.01)$ & LOD & $22,620.79$ & LOD & $20,983.27$ & \\
\hline$>36$ & 63 & $7.43(54.55)$ & $1.12(\mathrm{LOD}, 614.93)$ & 0.16 & $264,219.38$ & LOD & $13,418.01$ & \\
\hline \multicolumn{9}{|l|}{ Education } \\
\hline$\leq$ Middle school & 41 & $35.94(116.96)$ & 28.52 (LOD, 3257.32) & LOD & $264,219.38$ & LOD & $101,203.06$ & $<0.01$ \\
\hline High school & 86 & $7.59(20.75)$ & $9.41(\mathrm{LOD}, 55.54)$ & 0.16 & $22,620.79$ & LOD & 1918.31 & \\
\hline$\geq$ College & 30 & $2.60(9.89)$ & $2.91(\mathrm{LOD}, 21.18)$ & LOD & 1411.29 & LOD & 1010.85 & \\
\hline \multicolumn{9}{|l|}{ History of disease $^{\mathrm{a}}$} \\
\hline No & 127 & $9.57(36.07)$ & 8.44 (LOD, 125.22) & 0.16 & $264,219.38$ & LOD & $21,965.79$ & 0.83 \\
\hline Yes & 30 & $8.18(31.94)$ & 8.80 (LOD, 115.08) & LOD & 3723.77 & LOD & 8385.03 & \\
\hline \multicolumn{9}{|l|}{ Smoking } \\
\hline No & 51 & $5.31(38.62)$ & 1.24 (LOD, 282.81) & 0.16 & $109,600.22$ & LOD & $12,209.85$ & 0.17 \\
\hline Yes & 106 & $12.15(32.71)$ & $12.48(\mathrm{LOD}, 74.69)$ & LOD & $264,219.38$ & LOD & $19,048.45$ & \\
\hline \multicolumn{9}{|l|}{ Alcohol consumption } \\
\hline No & 119 & $10.77(37.53)$ & 9.99 (LOD, 232.80) & 0.16 & $264,219.38$ & LOD & $22,620.79$ & 0.36 \\
\hline Yes & 38 & $5.84(27.52)$ & $6.48(\mathrm{LOD}, 67.96)$ & LOD & 3723.77 & LOD & 3373.04 & \\
\hline \multicolumn{9}{|l|}{ Occupational exposure to BPA } \\
\hline No & 83 & $0.77(6.33)$ & $0.22(\mathrm{LOD}, 5.63)$ & 0.16 & 74.5 & LOD & 23.11 & $<0.01$ \\
\hline Yes & 74 & $199.13(19.65)$ & $180.59(23.39,1928.01)$ & 0.74 & $264,219.38$ & 1.45 & $23,979.51$ & \\
\hline \multicolumn{9}{|l|}{ Categories by urine BPA level } \\
\hline BPA undetected (below LOD) ${ }^{b}$ & 53 & LOD & LOD (LOD, LOD) & LOD & LOD & LOD & LOD & $<0.01$ \\
\hline Low tertile (LOD-13.84) & 35 & $3.93(2.96)$ & $5.63(1.55,8.82)$ & 0.16 & 13.84 & 0.36 & 13.44 & \\
\hline Middle tertile (13.84-274.83) & 35 & $42.58(2.26)$ & $32.90(22.78,74.50)$ & 15.15 & 274.84 & 15.39 & 250.78 & \\
\hline Top tertile (>274.83) & 34 & $2937.79(5.48)$ & $2161.23(683.21,9771.63)$ & 282.81 & $264,219.38$ & 353.49 & $148,255.01$ & \\
\hline
\end{tabular}

a: Disease refers to any acute or chronic disease of the liver, kidney, or other organs. ${ }^{b}$ : The urine BPA values of undetectable were input as LOD/ $\sqrt{ } 2 .{ }^{c}:$ The urine BPA concentrations were natural $\log (\ln )$ transformed. ${ }^{\text {}}$ : Independent $t$-test or one-way ANOVA analysis. GM: Geometrical Mean. GSD: Geometric Standard Deviation. LOD: Limit of detection. 
The distribution of $5 \mathrm{hmC}$ of the sperm ACHE gene by occupational BPA exposure (yes or no) and categories of urine BPA levels are described in Table 2. The $5 \mathrm{hmC}$ rate of the sperm ACHE gene was higher in the BPA exposure group (median $1.075 \%$ vs. $0.54 \%$, respectively; $p=0.041$ ) compared to the control group. After potential confounders were adjusted for, subjects who were in the lowest, middle, and top tertiles of detected BPA had higher $5 \mathrm{hmC}$ rates than those with undetected BPA $(1.11 \%, 1.15 \%$, $0.945 \%$ vs. $0.52 \%$ ). The differences were statistically significant except for the top tertile group (Table 3 ).

Table 2. Distribution of the 5-hydroxymethylcytosine $(5 \mathrm{hmC})$ rate of the sperm acetylcholinesterase $(A C H E)$ gene by characteristics of the study population and BPA exposure.

\begin{tabular}{|c|c|c|c|c|c|c|}
\hline \multirow{2}{*}{ Groups } & \multicolumn{6}{|c|}{ 5hmC Rate of Sperm ACHE Gene } \\
\hline & $\mathbf{N}$ & 5 th $\%$ & 25 th $\%$ & 50 th $\%$ & 75th $\%$ & 95th $\%$ \\
\hline \multicolumn{7}{|l|}{ Occupational exposure to BPA } \\
\hline No & 83 & 0.12 & 0.27 & 0.54 & 1.35 & 2.41 \\
\hline Yes & 74 & 0.11 & 0.43 & 1.075 & 1.78 & 2.57 \\
\hline \multicolumn{7}{|l|}{ Categories by urine BPA level } \\
\hline BPA undetected & 53 & 0.11 & 0.22 & 0.52 & 1 & 1.81 \\
\hline Low tertile (LOD-13.84) & 35 & 0.15 & 0.44 & 1.11 & 2.07 & 2.49 \\
\hline Middle tertile (13.84-274.83) & 35 & 0.13 & 0.48 & 1.15 & 2.03 & 2.61 \\
\hline Top tertile $(>274.83)$ & 34 & 0.1 & 0.23 & 0.945 & 1.61 & 2.57 \\
\hline \multicolumn{7}{|l|}{ Age (years) } \\
\hline$<29$ & 55 & 0.11 & 0.36 & 0.58 & 1.74 & 2.43 \\
\hline $30-35$ & 39 & 0.11 & 0.36 & 0.84 & 1.69 & 2.61 \\
\hline$>36$ & 63 & 0.12 & 0.31 & 0.72 & 1.49 & 2.46 \\
\hline \multicolumn{7}{|l|}{ Smoking } \\
\hline No & 51 & 0.13 & 0.33 & 0.58 & 1.19 & 2.49 \\
\hline Yes & 106 & 0.11 & 0.37 & 0.75 & 1.66 & 2.56 \\
\hline \multicolumn{7}{|l|}{ Alcohol consumption } \\
\hline No & 119 & 0.11 & 0.36 & 0.84 & 1.61 & 2.56 \\
\hline Yes & 38 & 0.11 & 0.29 & 0.55 & 1.48 & 3.01 \\
\hline \multicolumn{7}{|l|}{ History of disease } \\
\hline No & 127 & 0.13 & 0.31 & 0.63 & 1.51 & 2.43 \\
\hline Yes & 30 & 0.05 & 0.43 & 0.93 & 1.81 & 2.61 \\
\hline
\end{tabular}

Table 3. Linear regression of BPA exposure and the $5 \mathrm{hmC}$ rate of the ACHE gene.

\begin{tabular}{|c|c|c|c|c|c|}
\hline \multirow{2}{*}{ Groups } & \multicolumn{5}{|c|}{ 5hmC Rate of Sperm ACHE Gene ${ }^{a}$} \\
\hline & $\mathbf{N}$ & Crude $\beta(95 \% \mathrm{CI})^{b}$ & Crude $p$-Value & Adjusted $\beta^{\text {bc }}(95 \% \mathrm{CI})$ & $p$-Value \\
\hline \multicolumn{6}{|l|}{ Occupational exposure to BPA } \\
\hline No & 83 & Ref & & Ref & \\
\hline Yes & 74 & $0.337(0.019,0.655)$ & 0.038 & $0.336(0.014,0.657)$ & 0.041 \\
\hline \multicolumn{6}{|l|}{ Categories by urine BPA level } \\
\hline BPA undetected & 53 & Ref & & Ref & - \\
\hline Low tertile (LOD-13.84) & 35 & $0.642(0.218,1.065)$ & 0.003 & $0.661(0.220,1.102)$ & 0.004 \\
\hline Middle tertile (13.84-274.83) & 35 & $0.67(0.246,1.093)$ & 0.002 & $0.682(0.237,1.127)$ & 0.003 \\
\hline Top tertile $(>274.83)$ & 34 & $0.276(-0.151,0.703)$ & 0.204 & $0.274(-0.160,0.708)$ & 0.213 \\
\hline \multicolumn{6}{|l|}{ Age (years) ${ }^{d}$} \\
\hline$<29$ & 55 & Ref & & Ref & \\
\hline $30-35$ & 39 & $0.106(-0.317,0.528)$ & 0.622 & $0.032(-0.395,0.458)$ & 0.883 \\
\hline$>36$ & 63 & $-0.019(-0.392,0.353)$ & 0.919 & $-0.036(-0.411,0.339)$ & 0.850 \\
\hline \multicolumn{6}{|l|}{ Smoking ${ }^{d}$} \\
\hline No & 51 & Ref & & Ref & \\
\hline Yes & 106 & $0.141(-0.2,0.48)$ & 0.416 & $0.176(-0.178,0.531)$ & 0.327 \\
\hline \multicolumn{6}{|l|}{ Alcohol consumption ${ }^{d}$} \\
\hline No & 119 & Ref & & Ref & \\
\hline Yes & 38 & $-0.124(-0.499,0.251)$ & 0.515 & $-0.141(-0.529,0.247)$ & 0.473 \\
\hline \multicolumn{6}{|l|}{ History of disease $^{\mathrm{d}}$} \\
\hline No & 127 & Ref & & Ref & \\
\hline Yes & 30 & $0.064(-0.34,0.47)$ & 0.755 & $0.063(-0.348,0.475)$ & 0.762 \\
\hline
\end{tabular}


The linear regression analysis using the continuous BPA level found that increasing BPA was associated with increased $5 \mathrm{hmC}$, but the association was marginally statistically significant $(\beta=0.046$, $95 \% \mathrm{CI}: 0.000,0.0092)$. When the analyses were repeated within each tertile of urine BPA levels and in the control group, we observed statistically significant linear associations between urine BPA levels and $5 \mathrm{hmC}$ among those in the middle tertile group ( $\beta=0.453,95 \% \mathrm{CI}: 0.070,0.835)$ and those in the control group (no occupational BPA exposure) $(\beta=0.144,95 \% \mathrm{CI}: 0.003,0.285)$ despite the markedly reduced sample size (Table 4).

Table 4. Linear regression of BPA exposure and the $5 \mathrm{hmC}$ rate of the sperm ACHE gene ${ }^{\mathrm{a}}$.

\begin{tabular}{|c|c|c|c|c|c|}
\hline Groups & $\mathbf{N}$ & Crude $\beta(95 \% \mathrm{CI})$ & Crude $p$-Value & Adjusted $\beta^{\mathrm{b}}(95 \% \mathrm{CI})$ & $p$-Value \\
\hline All subjects & 157 & $0.048(0.003,0.093)$ & 0.036 & $0.046(0.000,0.092)$ & 0.051 \\
\hline Low tertile (LOD-13.84) & 35 & $0.068(-0.229,0.366)$ & 0.642 & $0.104(-0.231,0.440)$ & 0.529 \\
\hline Middle tertile (13.84-274.83) & 35 & $0.402(0.025,0.779)$ & 0.002 & $0.453(0.070,0.835)$ & 0.021 \\
\hline Top tertile $(>274.83)$ & 34 & $0.160(-0.051,0.37)$ & 0.133 & $0.137(-0.097,0.370)$ & 0.242 \\
\hline Non-occupational exposure & 83 & $0.127(0.01,0.244)$ & 0.033 & $0.144(0.003,0.285)$ & 0.045 \\
\hline \multicolumn{6}{|l|}{ Age (years) ${ }^{c}$} \\
\hline$<29$ & 55 & & & & \\
\hline $30-35$ & 39 & $0.105(-0.317,0.528)$ & 0.622 & $0.087(-0.337,0.512)$ & 0.685 \\
\hline$>36$ & 63 & $-0.019(-0.391,0.353)$ & 0.919 & $-0.005(-0.38,0.371)$ & 0.981 \\
\hline \multicolumn{6}{|l|}{ Smoking ${ }^{c}$} \\
\hline No & 51 & & & & \\
\hline Yes & 106 & $0.141(-0.2,0.48)$ & 0.416 & $0.122(-0.236,0.48)$ & 0.501 \\
\hline \multicolumn{6}{|l|}{ Alcohol consumption ${ }^{\mathrm{c}}$} \\
\hline No & 119 & & & & \\
\hline Yes & 38 & $-0.123(-0.499,0.251)$ & 0.515 & $-0.122(-0.511,0.268)$ & 0.537 \\
\hline \multicolumn{6}{|l|}{ History of disease ${ }^{c}$} \\
\hline No & 127 & & & & \\
\hline Yes & 30 & $0.064(-0.34,0.47)$ & 0.755 & $0.065(-0.347,0.477)$ & 0.756 \\
\hline
\end{tabular}

\section{Discussion}

In the present study, we provide the first epidemiological evidence that BPA exposure is associated with increased $5 \mathrm{hmC}$ of the sperm $A C H E$ gene in men. The linear association is also observed among subjects without occupational BPA exposure.

Our findings are comparable to those found in previous studies that focused on $5 \mathrm{hmC}$ changes in response to endo- and exogenous factors [42,43]. Sanchezguerra et al. recently found that exposure to ambient PM10 could affect the blood genomic content of 5hmC [42].

An increasing number of studies have suggested that BPA may affect human health by epigenetic regulation $[13,19,44,45]$. The emerging epigenetic modification, $5 \mathrm{hmC}$, has been shown to play a role in regulating gene function during the differentiation of spermatogenic cells [46,47]. There is evidence that $A C H E$ overexpression or activity is detected in apoptotic cells after the induction of apoptosis by different stimuli in many different type cells, such as hematopoietic stem cells, human neuroblastoma cells, and other cell lines $[29,30,48]$. The molecular mechanism underlying these effects is likely that ACHE promotes caspase-9 activation to increase nuclear condensation and polymerase cleavage [29,49-51]. Some studies reported that the transcriptional activity of the gene could be enhanced by DNA hypomethylation [46], which indicates that DNA hydroxymethylation in the ACHE promoter raises the gene activity. Abnormal $A C H E$ expression is reported to be associated with sperm counts and motility [31]. This is supported by a recent report that the $5 \mathrm{hmC}$ rate of the sperm ACHE gene is higher in asthenozoospermia and oligoasthenozoospermia men than in normozoospermia men [52]. In our study, the higher rate of $5 \mathrm{hmC}$ of the sperm $A C H E$ gene in subjects was associated with higher BPA exposure. This suggests the presence of upregulation of ACHE activity in the sperm from BPA-exposed men, which may eventually contribute to poor sperm concentration in the 
BPA-exposed men whom we had observed [12]. Our result is also in line with our previous report on the genome-wide upregulation of DNA 5'-hydroxymethylation in the spermatozoa of men exposed to BPA [23]. However, further studies need to be done to understand the changes in sperm quality across $5 \mathrm{hmC}$ levels.

A growing body of literature has reported adverse effects following developmental exposure to low doses of BPA $[53,54]$. Male rodents exposed to low levels of BPA displayed health impacts including altered serum testosterone levels and sperm quality [54,55]. In the present study, we did not observe a stronger association in the subgroup with the highest BPA exposure. In addition, we observed a similar association among the unexposed group. This non-monotonic effect is consistent with previous reports $[53,56,57]$, in which the biological effect of BPA is not always stronger in high dose exposure than low dose exposure.

The relationship between environmental exposures and $5 \mathrm{hmC}$ of the sperm $A C H E$ gene has not been reported previously. Our findings may have implications for understanding environmental exposure-induced male infertility via measuring $5 \mathrm{hmC}$ of the sperm $A C H E$ gene. Measuring the levels of $5 \mathrm{hmC}$ in semen specimens rather than other tissues to assess the potential epigenetic effect of BPA on semen quality is straight-forward and accurate. However, there are some limitations in our study. First, we did not investigate sperm $A C H E$ gene expression in this study because of the limited amount of individual semen samples. Next, we only detected one CpG site near the transcription start site (TSS) in the ACHE promoter region, which could not fully describe the relationship between the $5 \mathrm{hmC}$ of $A C H E$ and its transcript expression level. Third, the high occupational exposure has restricted the generalizability of the present study. BPA concentrations of some subjects in the top tertile group in the present study are much higher than those reported in the USA [58]. However, in the present study, we did not observe a stronger association in the subgroup with the highest BPA exposure. It is less likely that the observed association can be explained by the extremely high exposure. Fourth, the levels of BPA were measured based on a single spot urine sample (the unexposed group) or samples pre and post one shift (the exposed group), which may not be perfect surrogates of long-term BPA exposure, thus attenuating the observed association due to non-differential misclassification. However, it has been reported that a single urine sample can be relatively representative of exposure within a certain period [59]. Finally, similar to many studies collecting biological specimens, participants' refusal to provide biological samples (urine and/or semen) may lead to potential participation bias. However, since subjects in our study were not aware of both their BPA exposure and sperm ACHE hydroxymethylation levels before the biosamples were collected, the refusals may be considered random or undifferentiated in relation to exposure and outcome measures. Therefore, it seems unlikely that the observed association could be explained by participation bias.

\section{Conclusions}

In conclusion, our results indicate that $5 \mathrm{hmC}$ of the sperm ACHE gene is positively associated with BPA exposure. This provides supportive evidence for the effects of BPA on male fertility and other environmental exposure-related diseases.

Supplementary Materials: The following are available online at http:/ / www.mdpi.com/1660-4601/16/1/152/s1, Table S1: The differences of pre-shift and post-shift BPA levels in BPA-exposed group, Table S2: The difference of urine BPA in men with different education category

Author Contributions: Data curation, M.M. and X.Z.; Methodology, M.M., R.L., H.L. and W.Y.; Project administration, M.M. and H.L.; Writing—original draft, X.S.; Writing-review \& editing, X.S., M.M., X.Z., D.L., Y.T., R.L., H.L. and W.Y.

Funding: This work was supported by grants from the National Natural Science Foundation of China (grant numbers 81501318, 81571495); the National Key Research and Development Program (grant number 2016YFC1000505); the National Basic Research Program of China (grant number 2014CB943104); Science and Technology Commission of Shanghai Municipality (grant numbers 15431902800, 15140903100), Shanghai Municipal Commission of Health and Family Planning (grant numbers 201840184, 15GWZK0201), and Innovation-Oriented Science and Technology Grant from NPFPC Key Laboratory of Reproduction Regulation (CX2017-06 and CX2017-07). 
Acknowledgments: The authors thank the participating factories for their cooperation, and the staff at the local Chinese Centers for Disease Control for their help with data collection.

Conflicts of Interest: The authors declare no conflict of interest. The funding sponsor had no role in the design of the study; in the collection analyses, or interpretation of data; in the writing of the manuscript, and in the decision to publish the results.

\section{References}

1. Martin, M.D. Exposure to Bisphenol A (BPA) from dental sealants is detectable in saliva and urine, and varies significantly between sealant formulations. J. Evid. Based Dent. Pract. 2007, 7, 79-80. [CrossRef] [PubMed]

2. Ehrlich, S.; Calafat, A.M.; Humblet, O.; Smith, T.; Hauser, R. Handling of thermal receipts as a source of exposure to bisphenol A. JAMA 2014, 311, 859-860. [CrossRef]

3. Huang, Y.Q.; Wong, C.K.; Zheng, J.S.; Bouwman, H.; Barra, R.; Wahlstrom, B.; Neretin, L.; Wong, M.H. Bisphenol A (BPA) in China: A review of sources, environmental levels, and potential human health impacts. Environ. Int. 2012, 42, 91-99. [CrossRef] [PubMed]

4. Peretz, J.; Vrooman, L.; Ricke, W.A.; Hunt, P.A.; Ehrlich, S.; Hauser, R.; Padmanabhan, V.; Taylor, H.S.; Swan, S.H.; VandeVoort, C.A.; et al. Bisphenol a and reproductive health: Update of experimental and human evidence, 2007-2013. Environ. Health Perspect. 2014, 122, 775-786. [CrossRef] [PubMed]

5. Lassen, T.H.; Frederiksen, H.; Jensen, T.K.; Petersen, J.H.; Joensen, U.N.; Main, K.M.; Skakkebaek, N.E.; Juul, A.; Jorgensen, N.; Andersson, A.M. Urinary bisphenol A levels in young men: Association with reproductive hormones and semen quality. Environ. Health Perspect. 2014, 122, 478-484. [CrossRef] [PubMed]

6. Xu, L.C.; Sun, H.; Chen, J.F.; Bian, Q.; Qian, J.; Song, L.; Wang, X.R. Evaluation of androgen receptor transcriptional activities of bisphenol A, octylphenol and nonylphenol in vitro. Toxicology 2005, 216, 197-203. [CrossRef] [PubMed]

7. Lee, H.J.; Chattopadhyay, S.; Gong, E.Y.; Ahn, R.S.; Lee, K. Antiandrogenic effects of bisphenol A and nonylphenol on the function of androgen receptor. Toxicol. Sci. 2003, 75, 40-46. [CrossRef] [PubMed]

8. Wang, T.; Li, M.; Chen, B.; Xu, M.; Xu, Y.; Huang, Y.; Lu, J.; Chen, Y.; Wang, W.; Li, X.; et al. Urinary bisphenol A (BPA) concentration associates with obesity and insulin resistance. J. Clin. Endocrinol. Metab. 2012, 97, E223-E227. [CrossRef]

9. Mandrioli, D.; Belpoggi, F.; Silbergeld, E.K.; Perry, M.J. Aneuploidy: A common and early evidence-based biomarker for carcinogens and reproductive toxicants. Environ. Health 2016, 15, 97. [CrossRef]

10. Cuomo, D.; Porreca, I.; Cobellis, G.; Tarallo, R.; Nassa, G.; Falco, G.; Nardone, A.; Rizzo, F.; Mallardo, M.; Ambrosino, C. Carcinogenic risk and Bisphenol A exposure: A focus on molecular aspects in endoderm derived glands. Mol. Cell. Endocrinol. 2017, 457, 20-34. [CrossRef]

11. Chen, J.; Saili, K.S.; Liu, Y.; Li, L.; Zhao, Y.; Jia, Y.; Bai, C.; Tanguay, R.L.; Dong, Q.; Huang, C. Developmental bisphenol A exposure impairs sperm function and reproduction in zebrafish. Chemosphere 2017, 169, 262-270. [CrossRef] [PubMed]

12. Li, D.K.; Zhou, Z.; Miao, M.; He, Y.; Wang, J.; Ferber, J.; Herrinton, L.J.; Gao, E.; Yuan, W. Urine bisphenol-A (BPA) level in relation to semen quality. Fertil. Steril. 2011, 95, 625-630. [CrossRef] [PubMed]

13. Miao, M.; Yuan, W.; Yang, F.; Liang, H.; Zhou, Z. Associations between Bisphenol A Exposure and Reproductive Hormones among Female Workers. Int. J. Environ. Res. Public Health 2015, 13240-13250. [CrossRef] [PubMed]

14. Ndaw, S.; Remy, A.; Jargot, D.; Robert, A. Occupational exposure of cashiers to Bisphenol A via thermal paper: Urinary biomonitoring study. Int. Arch. Occup. Environ. Health 2016, 89, 935-946. [CrossRef] [PubMed]

15. Sarigiannis, D.A.; Karakitsios, S.P.; Handakas, E.; Simou, K.; Solomou, E.; Gotti, A. Integrated exposure and risk characterization of bisphenol-A in Europe. Food Chem. Toxicol. 2016, 98, 134-147. [CrossRef] [PubMed]

16. Goldstone, A.E.; Chen, Z.; Perry, M.J.; Kannan, K.; Louis, G.M. Urinary bisphenol A and semen quality, the LIFE Study. Reprod. Toxicol. 2015, 51,7-13. [CrossRef] [PubMed]

17. Yuan, C.; Zhang, Y.; Liu, Y.; Wang, S.; Wang, Z. DNA demethylation mediated by down-regulated TETs in the testes of rare minnow Gobiocypris rarus under bisphenol A exposure. Chemosphere 2017, 171, 355-361. [CrossRef] [PubMed] 
18. Krausz, C.; Sandoval, J.; Sayols, S.; Chianese, C.; Giachini, C.; Heyn, H.; Esteller, M. Novel insights into DNA methylation features in spermatozoa: Stability and peculiarities. PLoS ONE 2012, 7, e44479. [CrossRef]

19. Miao, M.; Zhou, X.; Li, Y.; Zhang, O.; Zhou, Z.; Li, T.; Yuan, W.; Li, R.; Li, D.K. LINE-1 hypomethylation in spermatozoa is associated with Bisphenol A exposure. Andrology 2014, 2, 138-144. [CrossRef]

20. Tahiliani, M.; Koh, K.P.; Shen, Y.; Pastor, W.A.; Bandukwala, H.; Brudno, Y.; Agarwal, S.; Iyer, L.M.; Liu, D.R.; Aravind, L.; et al. Conversion of 5-methylcytosine to 5-hydroxymethylcytosine in mammalian DNA by MLL partner TET1. Science 2009, 324, 930-935. [CrossRef]

21. Hill, P.W.; Amouroux, R.; Hajkova, P. DNA demethylation, Tet proteins and 5-hydroxymethylcytosine in epigenetic reprogramming: An emerging complex story. Genomics 2014, 104, 324-333. [CrossRef] [PubMed]

22. Liu, Y.; Zhang, Y.; Tao, S.; Guan, Y.; Zhang, T.; Wang, Z. Global DNA methylation in gonads of adult zebrafish Danio rerio under bisphenol A exposure. Ecotoxicol. Environ. Saf. 2016, 130, 124-132. [CrossRef] [PubMed]

23. Zheng, H.; Zhou, X.; Li, D.K.; Yang, F.; Pan, H.; Li, T.; Miao, M.; Li, R.; Yuan, W. Genome-wide alteration in DNA hydroxymethylation in the sperm from bisphenol A-exposed men. PLoS ONE 2017, 12, e0178535. [CrossRef] [PubMed]

24. Branco, M.R.; Ficz, G.; Reik, W. Uncovering the role of 5-hydroxymethylcytosine in the epigenome. Nat. Rev. Genet. 2011, 13, 7-13. [CrossRef] [PubMed]

25. Ye, C.; Li, L. 5-hydroxymethylcytosine: A new insight into epigenetics in cancer. Cancer Biol. Ther. 2014, 15, 10-15. [CrossRef] [PubMed]

26. Chakraborty, J.; Nelson, L. Comparative study of cholinesterases distribution in the spermatozoa of some mammalian species. Biol. Reprod. 1976, 15, 579-585. [CrossRef] [PubMed]

27. Egbunike, G.N. Changes in acetylcholinesterase activity of mammalian spermatozoa during maturation. Int. J. Androl. 1980, 3, 459-468. [CrossRef]

28. Jin, Q.H.; He, H.Y.; Shi, Y.F.; Lu, H.; Zhang, X.J. Overexpression of acetylcholinesterase inhibited cell proliferation and promoted apoptosis in NRK cells. Acta Pharmacol. Sin. 2004, 25, 1013-1021.

29. Zhang, X.J.; Yang, L.; Zhao, Q.; Caen, J.P.; He, H.Y.; Jin, Q.H.; Guo, L.H. Induction of acetylcholinesterase expression during apoptosis in various cell types. Cell Death Differ. 2002, 9, 790-800. [CrossRef]

30. Zhang, X.J.; Greenberg, D.S. Acetylcholinesterase involvement in apoptosis. Front. Mol. Neurosci. $2012,5,40$. [CrossRef]

31. Mor, I.; Sklan, E.H.; Podoly, E.; Pick, M.; Kirschner, M.; Yogev, L.; Bar-Sheshet, I.S.; Schreiber, L.; Geyer, B.; Mor, T.; et al. Acetylcholinesterase-R increases germ cell apoptosis but enhances sperm motility. J. Cell. Mol. Med. 2008, 12, 479-495. [CrossRef] [PubMed]

32. Mor, I.; Grisaru, D.; Titelbaum, L.; Evron, T.; Richler, C.; Wahrman, J.; Sternfeld, M.; Yogev, L.; Meiri, N.; Seidman, S.; et al. Modified testicular expression of stress-associated "readthrough" acetylcholinesterase predicts male infertility. FASEB J. 2001, 15, 2039-2041. [CrossRef] [PubMed]

33. Li, D.K.; Zhou, Z.; Miao, M.; He, Y.; Qing, D.; Wu, T.; Wang, J.; Weng, X.; Ferber, J.; Herrinton, L.J.; et al. Relationship between urine bisphenol-A level and declining male sexual function. J. Androl. 2010, 31, 500-506. [CrossRef]

34. Vitku, J.; Heracek, J.; Sosvorova, L.; Hampl, R.; Chlupacova, T.; Hill, M.; Sobotka, V.; Bicikova, M.; Starka, L. Associations of bisphenol A and polychlorinated biphenyls with spermatogenesis and steroidogenesis in two biological fluids from men attending an infertility clinic. Environ. Int. 2016, 89-90, 166-173. [CrossRef] [PubMed]

35. Liao, C.; Kannan, K. Determination of free and conjugated forms of bisphenol A in human urine and serum by liquid chromatography-tandem mass spectrometry. Environ. Sci. Technol. 2012, 46, 5003-5009. [CrossRef]

36. Teeguarden, J.G.; Twaddle, N.C.; Churchwell, M.I.; Yang, X.; Fisher, J.W.; Seryak, L.M.; Doerge, D.R. 24-hour human urine and serum profiles of bisphenol A: Evidence against sublingual absorption following ingestion in soup. Toxicol. Appl. Pharmacol. 2015, 288, 131-142. [CrossRef]

37. Krishnan, K.; Gagne, M.; Nong, A.; Aylward, L.L.; Hays, S.M. Biomonitoring Equivalents for bisphenol A (BPA). Regul. Toxicol. Pharmacol. 2010, 58, 18-24. [CrossRef] [PubMed]

38. He, Y.; Miao, M.; Herrinton, L.J.; Wu, C.; Yuan, W.; Zhou, Z.; Li, D.K. Bisphenol A levels in blood and urine in a Chinese population and the personal factors affecting the levels. Environ. Res. 2009, 109, 629-633. [CrossRef] 
39. Kochmanski, J.; Marchlewicz, E.H.; Cavalcante, R.G.; Sartor, M.A.; Dolinoy, D.C. Age-related epigenome-wide DNA methylation and hydroxymethylation in longitudinal mouse blood. Epigenetics 2018, 13, 779-792. [CrossRef]

40. Öztürk, N.C.; Resendiz, M.; Öztürk, H.; Zhou, F.C. DNA Methylation program in normal and alcohol-induced thinning cortex. Alcohol 2017, 60, 135-147. [CrossRef]

41. Lopez, V.; Fernandez, A.F.; Fraga, M.F. The role of 5-hydroxymethylcytosine in development, aging and age-related diseases. Ageing Res. Rev. 2017, 37, 28-38. [CrossRef] [PubMed]

42. Sanchez-Guerra, M.; Zheng, Y.; Osorio-Yanez, C.; Zhong, J.; Chervona, Y.; Wang, S.; Chang, D.; McCracken, J.P.; Diaz, A.; Bertazzi, P.A.; et al. Effects of particulate matter exposure on blood 5-hydroxymethylation: Results from the Beijing truck driver air pollution study. Epigenetics 2015, 10, 633-642. [CrossRef] [PubMed]

43. Cheong, A.; Zhang, X.; Cheung, Y.Y.; Tang, W.Y.; Chen, J.; Ye, S.H.; Medvedovic, M.; Leung, Y.K.; Prins, G.S.; Ho, S.M. DNA methylome changes by estradiol benzoate and bisphenol A links early-life environmental exposures to prostate cancer risk. Epigenetics 2016, 11, 674-689. [CrossRef]

44. Mileva, G.; Baker, S.; Konkle, A.; Bielajew, C. Bisphenol-A: Epigenetic Reprogramming and Effects on Reproduction and Behavior. Int. J. Environ. Res. Public Health 2014, 11, 7537-7561. [CrossRef]

45. Kundakovic, M.; Champagne, F.A. Epigenetic perspective on the developmental effects of bisphenol A. Brain Behav. Immun. 2011, 25, 1084-1093. [CrossRef] [PubMed]

46. Gan, H.; Wen, L.; Liao, S.; Lin, X.; Ma, T.; Liu, J.; Song, C.X.; Wang, M.; He, C.; Han, C.; et al. Dynamics of 5-hydroxymethylcytosine during mouse spermatogenesis. Nat. Commun. 2013, 4, 1995. [CrossRef] [PubMed]

47. Efimova, O.A.; Pendina, A.A.; Tikhonov, A.V.; Parfenyev, S.E.; Mekina, I.D.; Komarova, E.M.; Mazilina, M.A.; Daev, E.V.; Chiryaeva, O.G.; Galembo, I.A.; et al. Genome-wide 5-hydroxymethylcytosine patterns in human spermatogenesis are associated with semen quality. Oncotarget 2017, 8, 88294. [CrossRef] [PubMed]

48. Pegan, K.; Matkovic, U.; Mars, T.; Mis, K.; Pirkmajer, S.; Brecelj, J.; Grubic, Z. Acetylcholinesterase is involved in apoptosis in the precursors of human muscle regeneration. Chem. Biol. Interact. 2010, 187, 96-100. [CrossRef]

49. Jiang, H.; Zhang, X.J. Acetylcholinesterase and apoptosis. A novel perspective for an old enzyme. FEBS J. 2008, 275, 612-617. [CrossRef]

50. Park, S.E.; Kim, N.D.; Yoo, Y.H. Acetylcholinesterase plays a pivotal role in apoptosome formation. Cancer Res. 2004, 64, 2652-2655. [CrossRef]

51. Xie, J.; Jiang, H.; Wan, Y.H.; Du, A.Y.; Guo, K.J.; Liu, T.; Ye, W.Y.; Niu, X.; Wu, J.; Dong, X.Q.; et al. Induction of a $55 \mathrm{kDa}$ acetylcholinesterase protein during apoptosis and its negative regulation by the Akt pathway. J. Mol. Cell Biol. 2011, 3, 250-259. [CrossRef] [PubMed]

52. Li, Y.; Li, Y.H.; Zhou, X.; Wu, B.; Chen, J.P.; Wang, Z.K.; Wang, X.; Shi, H.J.; Li, R.S. DNA hydroxymethylation rate in the AChE and HoxC4 promoter associated with human sperm quality. Andrologia 2018, 50, e12963. [CrossRef] [PubMed]

53. Newbold, R.R.; Jefferson, W.N.; Padilla-Banks, E. Prenatal exposure to bisphenol A at environmentally relevant doses adversely affects the murine female reproductive tract later in life. Environ. Health Perspect. 2009, 117, 879-885. [CrossRef] [PubMed]

54. Vandenberg, L.N.; Colborn, T.; Hayes, T.B.; Heindel, J.J.; Jacobs, D.J.; Lee, D.H.; Shioda, T.; Soto, A.M.; Vom, S.F.; Welshons, W.V.; et al. Hormones and endocrine-disrupting chemicals: Low-dose effects and nonmonotonic dose responses. Endocr. Rev. 2012, 33, 378-455. [CrossRef] [PubMed]

55. Rhomberg, L.R.; Goodman, J.E. Low-dose effects and nonmonotonic dose-responses of endocrine disrupting chemicals: Has the case been made? Regul. Toxicol. Pharmacol. 2012, 64, 130-133. [CrossRef]

56. Wang, Z.; Li, D.; Miao, M.; Liang, H.; Chen, J.; Zhou, Z.; Wu, C.; Yuan, W. Urine bisphenol A and pubertal development in boys. Int. J. Hyg. Environ. Health 2017, 220, 43-50. [CrossRef]

57. Vom, S.F.; Timms, B.G.; Montano, M.M.; Palanza, P.; Thayer, K.A.; Nagel, S.C.; Dhar, M.D.; Ganjam, V.K.; Parmigiani, S.; Welshons, W.V. Prostate enlargement in mice due to fetal exposure to low doses of estradiol or diethylstilbestrol and opposite effects at high doses. Proc. Natl. Acad. Sci. USA 1997, 94, 2056-2061. 
58. Hines, C.J.; Jackson, M.V.; Deddens, J.A.; Clark, J.C.; Ye, X.; Christianson, A.L.; Meadows, J.W.; Calafat, A.M. Urinary Bisphenol A (BPA) Concentrations among Workers in Industries that Manufacture and Use BPA in the USA. Ann. Work Expos. Health 2017, 61, 164-182. [CrossRef]

59. Adoamnei, E.; Mendiola, J.; Vela-Soria, F.; Fernandez, M.F.; Olea, N.; Jorgensen, N.; Swan, S.H.; Torres-Cantero, A.M. Urinary bisphenol A concentrations are associated with reproductive parameters in young men. Environ. Res. 2018, 161, 122-128. [CrossRef]

(C) 2019 by the authors. Licensee MDPI, Basel, Switzerland. This article is an open access article distributed under the terms and conditions of the Creative Commons Attribution (CC BY) license (http:/ / creativecommons.org/licenses/by/4.0/). 